\title{
CEZARY WINKOWSKI
}

\begin{abstract}
A B S TR A C T
Business management is a continuous decision-making process. It is difficult to imagine a company that does not use forecasting techniques. Even small enterprises without relevant forecasting departments more or less consciously anticipate future events, forecasting the volume of production and setting directions for development. Today's production companies must quickly adapt to changing customer requirements, implementing structural and technological changes and delivering projects related to the production of new products. Under the dynamically changing conditions, the functioning and effective management of modern enterprises depend on futureoriented information. This increases the validity of forecasting. This article aimed to identify forecasting methods and areas of their use in production engineering. The publications on this subject were reviewed in the Scopus database, using the time frame from January 1970 to June 2018. An original classification of research subareas was created using VOS viewer software, and then, a bibliometric map was developed to visualise the results of the word coexistence analysis. The analysis of the co-occurrence and co-classification of words made it possible to indicate research subareas of forecasting in production engineering and related emerging research areas and issues.
\end{abstract}

KEY WORDS

forecasting, forecasting methods, production engineering, manufacturing company

DOI: 10.2478/emj-2019-0030
Corresponding author:

Cezary Winkowski

Bialystok University of Technology, Poland e-mail: c.winkowski@pb.edu.pl

\section{INTRODUCTION}

For manufacturing companies, forecasting is part of the decision system. It is a future-oriented activity based on data from the past. It makes it easier for managers and planners to make decisions. The right choice means that an enterprise generates profits, reduces the risk of errors and losses. Forecasting is one of the basic elements when making decisions in the area of production. As forecasting is one of the key elements during the decision-making process in production, it was decided to conduct a bibliometric analysis to assess the dynamics of interest in this subject, reflected by the number of publications in the analysed period. The review of the publications was made in the Scopus database. The database was chosen because of its size and availability. Prognostic 
methods and subareas of their use in production engineering were identified. In the next stage, the classification of research subareas was created using VOS viewer software, and then, a bibliometric map was developed to visualise the results of the word coexistence analysis.

The article aims to identify the areas of research analysed in the literature concerning forecasting in production engineering. This measure represents the first stage of the research process, aiming to identify research problems in the field and a solution, which would constitute a theoretical and practical contribution to the development of production forecasting model. All the considerations and research in the field of discussed issues are covered in the following four chapters. The first chapter presents the topics addressed by authors in the context of production forecasting. Next, the methodology used for bibliometric analysis is described. The third chapter presents the results of the conducted bibliometric analysis. The final part analyses the obtained results and presents the conclusions.

\section{LITERATURE REVIEW}

According to the definition of a Polish-language dictionary, "method" is a way to scientifically examine things and phenomena, and a set of rules used to examine reality (Słownik Nowy Języka Polskiego, 2002). One of the frequently used definitions of "research method" was proposed by A. Kamiński: "A team of theoretically justified conceptual and instrumental measures that broadly cover the whole of the researcher's investigations, aimed at solving a specific scientific problem" (Kamiński, 1974, p. 65). The current collection of forecasting methods is incredibly rich. It contains methods derived from many scientific disciplines. Forecasting methods can be divided into the following categories (Korol, 2010; Nazarko, 2004; Cortez et al., 1995; Box and Jenkins, 1970):

- methods of analysis and forecasting of time series, in which data regarding the current development of the forecasted variable and information are used in relation to current and future factors affecting the course of its development. Data analysis allows determining the correctness of development of the forecasted variable. The choice of the right model is based on the decomposition of the time series, which makes it possible to isolate the existing components in the analysed series and determining their mutual relations;

- statistical methods, in which forecasting is based on past regularities, regardless of the reason for their formation;

- analogue methods, in which with the future value of the variable is estimated based on data with similar variables that are causally unrelated to the projected variable;

- methods of cause-and-effect prediction, in which model parameters are determined based on a sample containing time series, cross-sectional or time-cross-sectional variables occurring in the model;

- heuristic methods (expert), in which opinions from several to several dozen experts are based on their experience and intuition.

According to the above classification, several forecasting methods are available with some being less and others more universal. Therefore, the identification of prognostic methods and subareas of their use in production engineering was made. Based on the review of the literature, topics presented by the authors in the context of production forecasting was presented.

The production of oil and gas is the dominating area, in which production forecasting is used. Crude oil, referred to as "black gold", is crucial for the global economy as a raw material of the chemical industry, but primarily, as one of the most important energy resources (Ejdys et al., 2014). Among all the articles, the majority concerned this subject. An example of a publication that discusses the production forecasting of both these raw materials is the study by Clark, Lake and Patzek. The authors recommend using a logistic trend model in this type of forecast (Clark et al., 2011). This model belongs to the group of analytical methods, in which the estimation is calculated by calculating the value of the appropriate function for the future moment of time. This assumes the invariability of the model until the forecast is determined (Maciąg et al., 2013). In turn, Wickens and De Jonge presented the process of forecasting oil production using the IAM model (Integrated Asset Model), which is used in the oil industry. This model includes probabilistic forecasts of plant performance and production, enabling an analysis of decision risk for strategic and operational decisions (Wickens and Jonge, 2006). In their article, Zhang, Orangi, Bakshi, Da Sie and Prasanna described the design and implementation of a prototype set of tools that demonstrated the functionality of the IAM model thanks to 
the integrated production and forecasting process (Zhang et al., 2006). In most studies, SSN was used to forecast production. The artificial network is a collection of interconnected elements called neurons (Ejdys et al., 2015). To predict oil production, Zhou and Liu used the BPNN (backpropagation neural network). The reverse propagation algorithm consists of such a change in the weight of the input signals of each neuron in each layer so that the error for the next learning pairs is as small as possible (Guanwu et al., 2017). Model verification yielded satisfactory results because of the network training process, which resulted in predicted values that were very good for real values (Zhou and Liu, 2009). In turn, Zhao, Huang, Li, and Zhang expanded BPNN based on the genetic algorithm (GA-BPNN), which allowed to obtain lower MAPE results than using BP neural networks. The authors used GA-BPNN to predict water abstraction and gas production in the process of optimising the anaerobic treatment of wastewater fermentation (Zhao et al., 2018). In contrast, Yang, Lin, Gong and Zhou combined the classic BP model with the dynamic particle swarm method to accurately predict the production of methane from coal seams. They developed a novel model of the neural network (DPSO-NN), which found application and efficiency in engineering prediction (Yang et al., 2018). In one of their earlier articles, Meling, Morkeseth and Langeland used a stochastic and analytical model to predict gas production (Meling et al., 1988). Sagheer and Kotb dealt with the limitation of traditional prognostic methods in the machine learning process. They proposed an approach to deep learning, which allowed to eliminate the limitations associated with traditional methods of forecasting. The proposed approach was a long-term short-term memory (DLSTM) architecture, an extension to the traditional repetitive neural network. The genetic algorithm has been used to optimally configure the DLSTM architecture. For verification purposes, production data of two oil fields were given. The proposed DLSTM model had better results than traditional prognostic methods (Sagheer and Kotb, 2018). Aizenberg et al. presented multilayer $\mathrm{NN}$ with multivalent neurons capable of predicting oil production based on time series. This model is built based on a neural network with a complex structure with a derivative-free backpropagation algorithm (Aizenberg et al., 2016).

Another area covered in the production forecasting publications is the forecasting of energy production. For this purpose, the authors of the publication most often use artificial neural networks. For exam- ple, $\mathrm{Xu}$, Chen, Tang, and $\mathrm{Li}$ addressed the problem of forecasting energy production for a generation system connected to the BIPV (Building Integrated Photovoltaic) network. The authors stated that artificial intelligence methods, such as artificial neural networks, were the developmental direction for the modelling of energy production forecasting used for generation systems connected to the BIPV network (Xu et al., 2012). Theocharides, Makrides, Georghiou and Kyprianou used artificial neural networks (ANN), regression of the support vector (SVR) and regression tree (RT) to predict photovoltaic (PV) production with different parameters and properties. Their main goal was to assess the performance of various machine learning models to determine the output power of PV systems. The output prediction efficiency of the models was tested on actual PV production data and evaluated based on absolute percentage error (MAPE), and normalised core mean square error (nRMSE). A comparative analysis showed that artificial neural networks were the best because of the smallest errors (Theocharides et al., 2018). To predict PV production, Gligor, Dumitru and Grif used artificial intelligence, which predicted and managed the production of a PV power plant located in the central part of Romania. Its main task was to develop a solution that forecasted electricity production in real-time based on historical and current solar radiation data (Gligor et al., 2018). Wasilewski proposed the ARIMAX model for shortterm forecasting of electricity production (Wasilewski, 2014). It is an extension of the ARIMA model that includes additional exogenous variables " $\mathrm{X}$ " in the model (Chunyan and Jun, 2009). Jones applied a combination of the ARIMAX model and hypothesis testing to forecasting in the power sector. Hypothesis testing refers to formal procedures used by statisticians to accept or reject the statistical hypothesis (Jones, 2004).

The next area that uses production forecasting is the production in industrial agriculture. For example, Rahmat et al. used an adaptive neuro-fuzzy inference system (ANFIS) to predict the production of rubber milk (Rahmat et al., 2018). Qader, Dash and Atkinson attempted to predict the production volume of wheat and barley in arid and semi-arid regions, which were the main cereal crops in many parts of the world and their production influenced local food safety. The authors used remotely sensed primary productivity and crop phenology (Qader et al., 2018). In turn, Mustafa and Jbara used the ARIMA model to forecast wheat production (Mustafa and Jbara, 2018). Also, 
Farhan, Hassnain, Irum and Abdul used the ARIMA model for milk production in Pakistan (Farhan et al., 2011). Alam, Sinha et al. used the hybrid ARIMA model with the SSN approach to predict rice production. This hybrid model significantly reduced the MAPE compared with ARIMA alone (Alam et al., 2018). De Oliveira, Mendes-Moreira and Ferreira (2018) used four methods to forecast grape production. The selected methods were multivariate linear regression, regression trees, lasso and random forest. The selected methods were verified using the mean squared error and the coefficient of variation (de Oliveira et al., 2018).

Another identified field that uses production forecasts is the automotive industry. Lin, Wong and Ho indicated that the process of the production chain in the automotive industry is directly dependent on the accuracy of its production forecasting model (e.g., the level of safety stocks, lack of inventory or timeliness). This article presents the Chinese automotive industry as a case study. The authors present an integrated model based on the grey neural network, which is a combination of the GM model (grey model) and a neural network. The GM model can be used for prediction in non-linear time series. The model is used especially in situations where the number of observations is insufficient (Chunyan et al., 2016). Experimental results show that integrated models have higher prediction accuracy than a single GM model (grey model) and neural network (Lin et al., 2015). One of the branches of the automotive industry is the production of electric cars. An article by Wang and Li was found in the database regarding the use of a logistics trend model to forecast the production of this type of vehicles. The conclusions drawn from the forecast indicate that global production of electric cars will enter the phase of rapid development (Wang and $\mathrm{Li}, 2011$ ). In turn, Ngadono and Ikatrinasari used the ARIMA model to forecast the production capacity to create a PVB film needed in the process of laminating car glass (Ngadono and Ikatrinasari, 2018). In contrast, Subramaniyan, Skoogh, Salomonsson, Bangalore and Bokrantz developed an algorithm for predicting bottlenecks on production lines in the automotive industry. They combined the ARIMA methodology with a real-databased technique, making it easier for engineers to manage bottlenecks and achieve higher bandwidth (Subramaniyan et al., 2018). Lai, Shui and Ni used a Two-Layer Long Short-Term Memory (LSTM) to predict bottlenecks on the chassis assembly line. This neural network-based approach takes advantage of the historical high dimensional factory floor data to make real-time predictions considering future production planning inputs (Lai et al., 2018). To predict production in the Chinese automotive industry, Lin, Wong and Ho presented three kinds of combined models based on a grey neural network, namely, a parallel grey neural network, series grey neural network, and inlaid grey neural network compared the single model GM and neural network. The experimental results demonstrated that the combined models had higher forecasting accuracy than the single model (Lin et al., 2014).

Other publications identified in the database did not concern production forecasting directly. They mainly concerned demand forecasting (Stanton et al., 1969; Raine, 1971; Tong and Sun, 2010; Li and Lim, 2018), further sales (Yelland, 2011) and forecasting in the supply chain (Liang, 2016).

\section{RESEARCH METHODS}

To identify methods and areas of forecasting in production engineering, and due to the review nature of the publication, the bibliometric analysis method was used as a research method. A review of the publication was made in the Scopus database. The selection of the database was made due to its size and availability. The first formulation, based on which the database was searched, was forecasting in production engineering used in article titles, abstracts and keywords. As a result of the search, only one publication was found, entitled "Technological forecasting and production engineering research" from 1970. This paper describes the qualitative and quantitative methods of forecasting technology and presents the results of forecasts using the Delphi method (Merchant, 2018). Because no satisfactory results were derived from the exploration of publications using the above combination of words, the phrase was modified. The aim was to remain as close as possible to the original wording and stay related to the studied subject. The most accurate phrase to explore the database was production forecasting used in article titles, abstracts and keywords. The time frame of the analysed period covered the years from January 1970 to June 2018.

In the second part of the research, the coexistence of words was assessed as well as their co-classification in publications. The method used to analyse the coexistence of words was based on counting the sequence of words appearing in the text. Using the VOS viewer software, a bibliometric map was devel- 
oped, which is a visualisation of the results of the word coexistence analysis (Halicka, 2017; Gudanowska, 2017; Siderska \& Jadaa, 2018; Szpilko, 2017, Winkowska et al., 2019). The size of the circles reflects the number of specific words, while the distance between the circles depends on the number of coexistences (Halicka, 2016). This method enabled the creation of the classification of forecasting methods in production engineering.

\section{RESEARCH RESULTS}

Exploration of Scopus database resulted in 726 studies found registered in the database, of which the largest part (Fig. 1) was composed of conference proceedings, the number of which was 403 (55.5\%), articles -278 (38.3\%), and conference reviews - 25 (3.4\%).
Most publications were created in the United States (215 articles), China (69 articles), Canada (57 articles) and Great Britain (35 articles). In the next step, it was decided to analyse the interest in the subject matter over the years. The time frame of the analysed period covered the years from January 1970 to June 2018, because the oldest publication came from 1970. The number of studies published in individual years is shown in Fig. 2.

For many years of the analysed period, the interest in the subject of forecasting production was moderate and remained rather low. It was only from around 2010 that an upward trend could be observed in the context of the number of studies related to the studied subject. A particularly dynamic increase in the number of publications started in 2012. In the years 2014-2017, the number of articles remained rather steady:

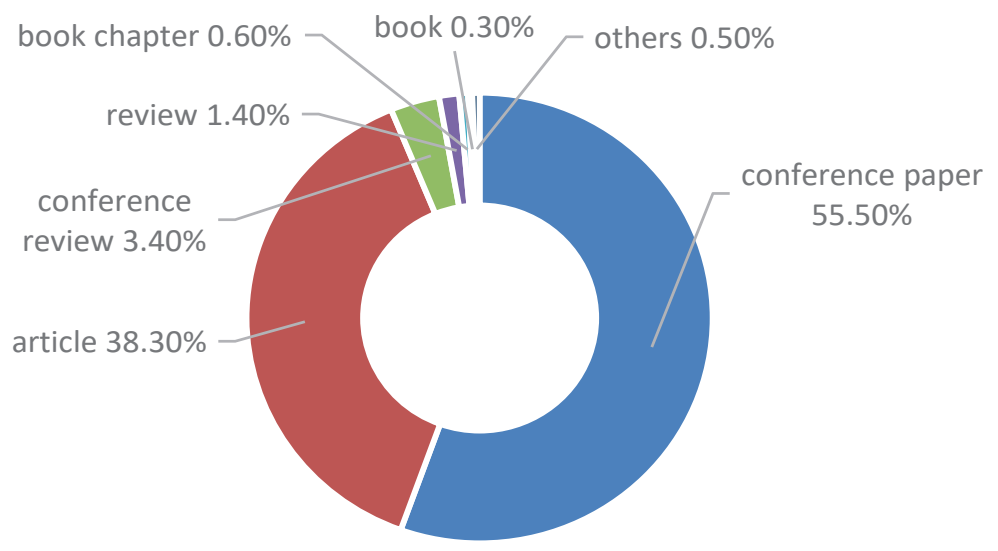

Fig. 1. Results of searching the Scopus database - the document type criterion

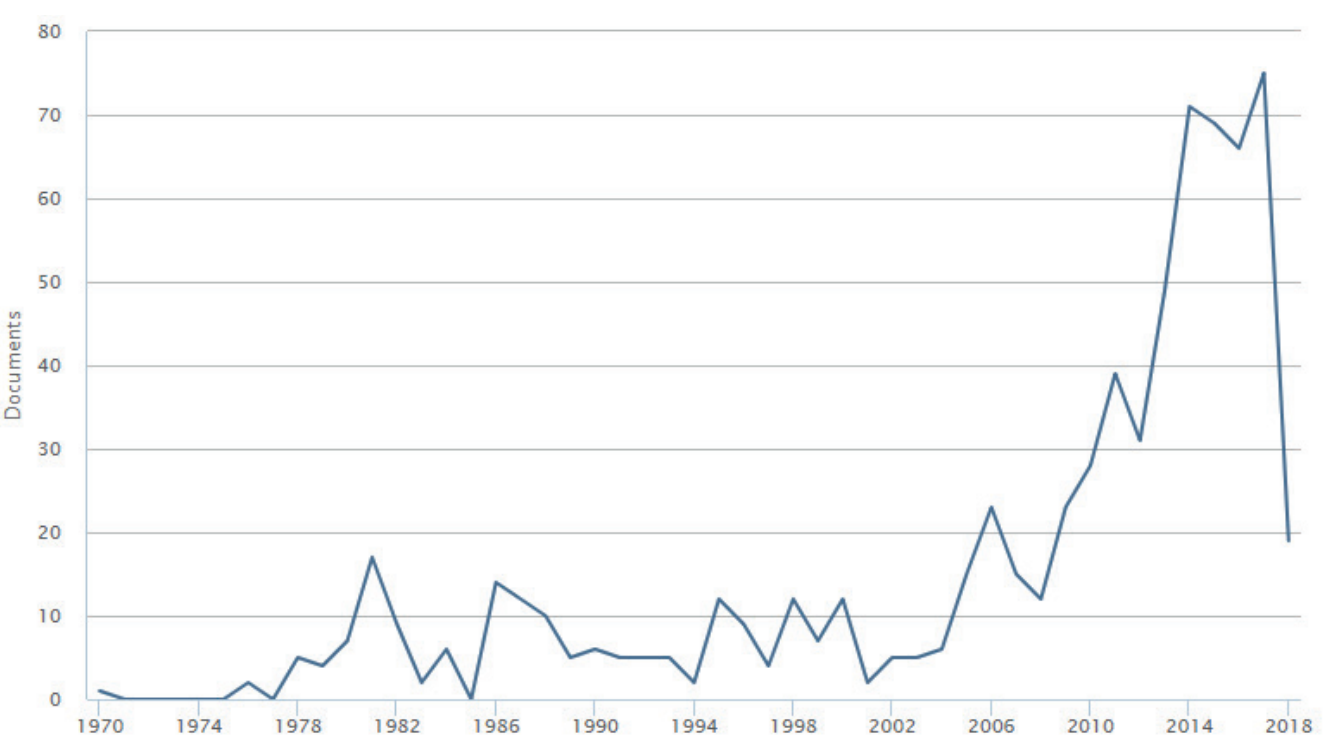

Fig. 2. Number of publications in the field of production forecasting in the Scopus database indexed January 1970 to June 2018 
- $2014-71$ publications;

- 2015 - 69 publications;

- 2016 - 66 publications;

- 2017 - 75 publications.

However, this is still not much, so it may mean that production forecasting is a topic that has not been thoroughly explored yet and is of interest both to researchers, researchers and production managers. Cooperation between enterprises and scientific institutions are the main actions required for successful development (Radziszewski et al., 2016, p. 168).

In the next stage, the classification of research subareas was created using the VOS viewer software, and then, a bibliometric map was developed, which is a visualisation of the results of the word coexistence analysis. The results of the analysis of articles from the Scopus database are presented in Fig. 3.

The word coexistence analysis made it possible to distinguish three clusters - A, B and C. Each cluster represents a specific group of methods used in forecasting in production engineering. The following subgroups have been identified:

- Cluster A - classical methods;

- Cluster B - artificial intelligence methods;

- Cluster C - hybrid methods.

\section{DISCUSSION OF THE RESULTS}

The first cluster $-\mathrm{A}-$ includes forecasting methods in production engineering defined by the author as classical. This group includes forecasting methods that can be classified as the oldest methods used in production engineering, which are strongly represented in the literature. Many studies describe these methods. It is a group that covers numerical methods, statistical (ANOVA, NARX model, comprehensive statistical analysis, statistical method), analytical (analytical technique, analytical production prediction, linearization, nonlinear function), qualitative models, probabilistic methods (probabilistic forecasting approach, probabilistic prediction), time series methods (time series analysis), trend analysis methods, fuzzy time series, regression and autoregression models (mean kriging, non linear regression, ARIMA, ARMA, autoregressive model, autoregression), simulation methods (Monte Carlo simulation, Monte Carlo analysis). It is the most copious of the three groups of methods identified during the study. Currently, many researchers aiming to determine the most accurate forecast of production,

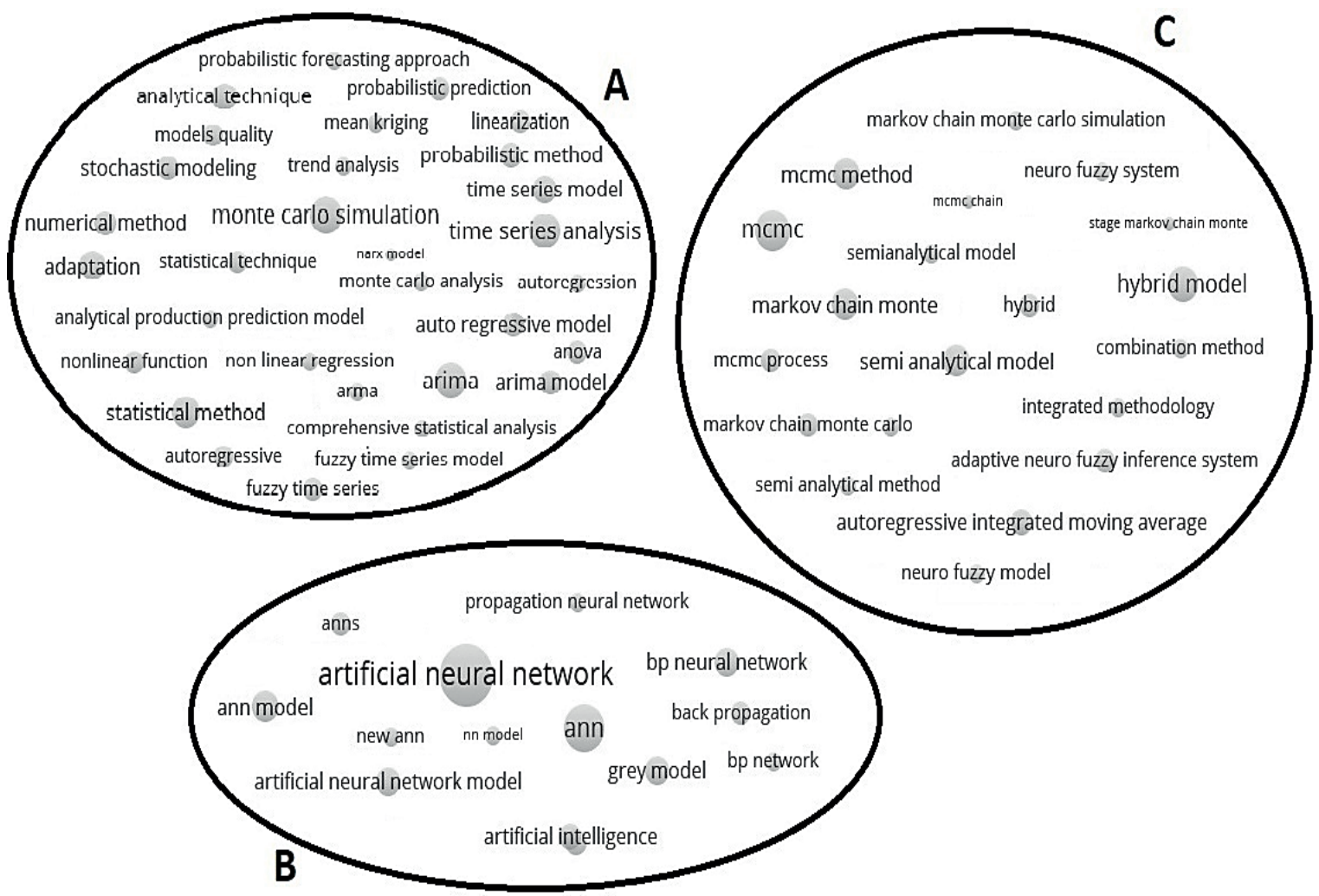

Fig. 3. Classification of forecasting methods in production engineering 
depart from the use of only one of these methods, favouring a combination. More specifically, the process of combining methods was described in cluster C.

Cluster B contained artificial intelligence methods. Artificial intelligence is one of the top themes these days. It is used in many areas, including forecasting production. Often, artificial intelligence methods allow obtaining more accurate predictions and smaller errors in production forecasts. The literature analysis made it possible to indicate artificial intelligence methods most often used in forecasting in production engineering. Among them were the propagation neural network, the backpropagation neural network and the grey model.

The last cluster - C - covered hybrid methods, i.e., sets of methods that were a mixture of classical methods and artificial neural networks, as well as ANN-ANN combinations. This can be described as an integrated approach. Based on the literature analysis, such hybrids could allow obtaining the best results in forecasting production because such synergies enable to use the strengths of the selected methods. Depending on the type and specifics of the manufacturing industry and the nature of the data, the appropriate prognostic method should be chosen. This indicates a scientific gap that requires further research. The literature has no clear indication related to the effect made by matching methods, principles used to choose methods and factors on the choice of a forecasting method in production engineering.

The co-occurrence analysis and the co-classification of words made it possible to identify three clusters that constituted research subareas in the context of forecasting in production engineering. Tab. 1 indicates the research subareas of forecasting in production engineering and related emerging research directions and issues.

Based on the problems solved using individual groups of methods, conclusions can be drawn about their specificity. Classic forecasting methods are used for rather simple issues. On the other hand, methods from clusters B and C are advanced, intelligent methods that not only allow obtaining information based on available data but also allow modelling production processes. According to the author, hybrid methods - the combination of classic methods and artificial intelligence methods - allow creating a forecasting model that uses the advantages of both approaches, which simultaneously increases the accuracy and quality of the forecast and extends the possibilities of using the model.

\section{CONCLUSIONS}

Forecasting production is one of the key stages ensuring the correct course of business. Based on information from the forecast, managers make key decisions. Determining the right forecast requires the correct use of production data. Forecasts allow companies to maximise profits, reduce the risk of improper decisions, errors and losses. The publication aimed to review the literature in the field of production forecasting. It was carried out in the Scopus database, and the time frame of the analysed period covered 48 years (1970-2018). In the analysed period, the initial interest in the subject was low. Increasingly

Tab. 1. Research subareas of forecasting in production engineering

\begin{tabular}{|c|c|c|c|}
\hline Cluster & GROUP OF METHODS & RESEARCH SUBAREAS & MAIN RESEARCH ISSUES \\
\hline$A$ & classical methods & $\begin{array}{l}\text { the possibility of obtain- } \\
\text { ing information that } \\
\text { objectively reflects the } \\
\text { economic situation of an } \\
\text { enterprise }\end{array}$ & $\begin{array}{l}\text { - forecasting of the prime cost of production based on the cal- } \\
\text { culation of the complex influence of production factors on } \\
\text { this indicator (Yureneva et al., 2020; Kuladzhi et al., 2017; } \\
\text { Trubaev and Tarasyuk, 2017; Mustavaeva, 2007); } \\
\text { - prediction of production volume (Tkachev et al., 2018; Mus- } \\
\text { tavaeva, 2007; Dupré et al., 2020; Artun et al., 2014); } \\
\text { - } \text { operational cost management (Barinova and Shikhova, 2016, } \\
\text { Yureneva and Barinova, 2016; Shim et al., 2009) }\end{array}$ \\
\hline B & $\begin{array}{l}\text { artificial intelli- } \\
\text { gence methods }\end{array}$ & $\begin{array}{l}\text { adaptive modelling of } \\
\text { production processes }\end{array}$ & $\begin{array}{l}\text { improve management processes (Alva et al. 2020; Tariq et al., } \\
\text { 2019; Sarma et al., 2018; Tariq, 2018; Jain et al., 2018); } \\
\text { - } \quad \text { predict cycle times of a common operation (Onaran and Ya- } \\
\text { nik, 2020; Gyulai et al., 2020; Okubo et al., 2020; Wang and } \\
\text { Jiang, 2019; Susanto et al., 2012; Eraslan, 2009) }\end{array}$ \\
\hline $\mathrm{C}$ & hybrid methods & $\begin{array}{l}\text { predictive modelling and } \\
\text { probabilistic forecasting }\end{array}$ & $\begin{array}{l}\text { - } \quad \text { planning of production volume (Elgharbi et al., 2020; Li et al., } \\
\text { 2018; Wu et al., 2017) }\end{array}$ \\
\hline
\end{tabular}


more publications were published every year. Until 2010, few studies were prepared. Later, the interest grew steadily, and then stabilised since 2014 and remained as such until now. In the last stage of the bibliometric analysis focused on the co-occurrence of words and their co-classification in publications. The word coexistence analysis was made using the VOS viewer software. A bibliometric map was prepared, and on this basis, the classification of forecasting methods in production engineering was made. Three groups of methods were distinguished - classical methods, artificial intelligence methods and hybrid methods, i.e., a mixture of classical methods and artificial neural networks as well as ANN-ANN combinations. In the age of the 4.0 industry, the importance of prognostic knowledge and knowledge of the use of artificial intelligence methods increases. Employers expect prognostic skills from managers in managerial positions. It is important to understand the future, and this can only be done by studying this field of science. As the manufacturing industry is varied, has numerous characteristics and specialises in different fields, there is no universal forecasting method that could be used by all manufacturing companies. As a result, various methods are combined, and integrated resource modelling is built to best match production data and, thus, result in more accurate forecasts. Aiming to find the criteria for the selection of combined methods and factors influencing their choice, research in this field of science should be continued.

\section{LITERATURE}

Abulhanova, G. A., Chumarina, G. R., Nikiforova, E. G., \& Sharifullina, T. A. (2016). Economic forecasting and personnel management of small and medium enterprises. Academy of Strategic Management Journal, 15(4), 67-75.

Aizenberg, I., Sheremetov, L., Villa-Vargas, L., \& MartinezMuñoz, J. (2016). Multilayer neural network with multi-valued neurons in time series forecasting of oil production. Neurocomputing, 175, 980-989.

Alam, W., Sinha, K., Kumar, R. R., Ray, M., Rathod, S., Singh, K. N., \& Arya, P. (2018). Hybrid linear time series approach for long term forecasting of crop yield. Indian Journal of Agricultural Sciences, 88(8), 1275-1279.

Alva, I., Rojas, \& J., Raymundo, C. (2020). Improving processes through the use of the $5 \mathrm{~S}$ methodology and menu engineering to reduce production costs of a MSE in the hospitality sector in the department of Ancash. Advances in Intelligent Systems and Computing, 1018, 818-824.
Artun, E., Vanderhaeghen, \& M., Murray, P. (2016). A pattern-based approach to waterflood performance prediction using knowledge management tools and classical reservoir engineering forecasting methods. Gas and Coal Technology, 13(1), 19-40.

Barinova, O. I., \& Shikhova, O. A. (2016). Methodological problems of milk cost forecasting in operational cost management. Innovative Way of Development of Agro-Industrial Complex: Collection of Scientific Works on Materials of XXXIX International ScientificPractical Conference of the Faculty (pp. 156-161).

Box, G., \& Jenkins, G. (1970). Time series Analysis: Forecasting and Control. San Francisco, United States: Holden-Day.

Chen, X. J., Tang, Z.-H., \& Li, J. F. (2012). Preliminary study on BIPV grid-connected generation system production forecasting. Dianli Xitong Baohu yu Kongzhi/ Power System Protection and Control 40(18), 81-85.

Chunyan, L., \& Jun, C. (2009). Traffic Accident Macro Forecast Based on ARIMAX Model. International Conference on Measuring Technology and Mechatronics Automation, 3, 633-636.

Cieślak, M. (Ed.). (2005). Prognozowanie gospodarcze. Metody i zastosowania [Economic forecasting. Methods and applications]. Warszawa, Poland: Wydawnictwo Naukowe PWN.

Clark, A. J., Lake, L. W., \& Patzek, T. W. (2011). Production forecasting with logistic growth models. Proceedings - SPE Annual Technical Conference and Exhibition, 1, 184-194.

Cortez, P., Rocha, M., Machado, J., \& Neves, J. (1995). A neural network-based time series forecasting system. Proceedings of IEEE International Conference on Neural Networks.

Czerwiński, Z. (1992). Dylematy ekonomiczne [Economic dilemmas]. Warszawa, Poland: Państwowe Wydawnictwo Ekonomiczne.

de Oliveira, R. C., Mendes-Moreira, J., \& Ferreira, C. A. (2018). Agribusiness intelligence: Grape production forecast using data mining techniques. Advances in Intelligent Systems and Computing, 747, 3-8.

Dupré, A., Drobinski, P. A., Alonzo, B. A., Badosa, J. A., Briard, C. C., \& Plougonven, R. (2020). Sub-hourly forecasting of wind speed and wind Energy. Renewable Energy, 145, 2373-2379.

Dzikevičius, A., \& Šaranda, S. (2011). Smoothing techniques for market fluctuation signals. Business: Theory and Practice, 12(1), 63-74.

Ejdys, J., Halicka, K., \& Godlewska, J. (2015). Prognozowanie cen energii elektrycznej na giełdzie energii [Forecasting electricity prices on the energy exchange]. Zeszyty Naukowe. Organizacja i Zarzadzanie. Politechnika Śląska, 77, 53-61.

Ejdys, J., Halicka, K., \& Winkowski, C. (2014). Predicting oil prices. Journal of Machine Construction and Maintenance, 92(1), 5-13.

Elgharbi, S., Esghir, M., Ibrihich, O., Abarda, A., El Hajji, S., \& Elbernoussi, S. (2020). Grey-Markov Model for the Prediction of the Electricity Production and Consumption. Lecture Notes in Networks and Systems, 81, 206-219. 
Eraslan, E. (2009). The estimation of product standard time by artificial neural networks in the molding industry. Mathematical Problems in Engineering, 2009, 1-12.

Eraslan, E., Farhan, A., Hassnain, S., Irum R., \& Abdul, S. (2011). Forecasting milk production in Pakistan. Pakistan Journal of Agricultural Research, 24(1-4), 82-85.

Gligor, A., Dumitru, C.-D., \& Grif, H.-S. (2018). Artificial intelligence solution for managing a photovoltaic energy production unit. Procedia Manufacturing, 22, 626-633.

Guanwu, J., Minzhou, L., Keqiang, B., \& Saixuan, C. (2017). A Precise Positioning Method for a Puncture Robot Based on a PSO-Optimized BP Neural Network Algorithm. Applied Sciences, 7(10), 1-13.

Gudanowska, A. E. (2017). A map of current research trends within technology management in the light of selected literature. Management and Production Engineering Review, 8(1), 78-88.

Gyulai, D., Pfeiffer, A., Nick, G., Gallina, V., Sihn, W., \& Monostori, L. (2018). Lead time prediction in a flow-shop environment with analytical and machine learning approaches. IFAC-PapersOnLine, 51(11), 1029-1034.

Halicka, K. (2016). Prospektywna analiza technologii - metodologia i procedury badawcze [Prospective technology analysis - research methodology and procedures]. Białystok, Poland: Oficyna Wydawnicza Politechniki Białostockiej.

Halicka, K. (2017). Main concepts of technology analysis in the light of the literature on the subject. Procedia Engineering, 182, 291-298.

Jae, R., Shim, J. K., \& Siegel, J. G. (2009). Modern Cost Management and Analysis. Barron's Educational Series.

Jain, A., Patel, N., Hammonds, P., \& Pandey, S. (2018). A smart software system for flow assurance management Society of Petroleum Engineers. SPE Asia Pacific Oil and Gas Conference and Exhibition.

Jones, D. (2004). Estimation of power system parameters. IEEE Transactions on Power Systems, 19(4), 19801989.

Kamiński, A. (1974). Metoda, technika, procedura badawcza w pedagogice empirycznej [Method, technique, research procedure in empirical pedagogy]. In R. Wroczyński, \& T. Pilch (Ed.), Metodologia pedagogiki społecznej [Methodology of social pedagogy]. Wrocław, Poland: Wydawnictwo PAN.

Kikolski, M., \& Ko, C. H. (2018). Facility layout design review of current research directions. Engineering Management in Production and Services, 10(3), 7079.

Korol, T. (2010). Systemy ostrzegania przedsiębiorstw przed ryzykiem upadłości [Systems warning companies about the risk of bankruptcy]. Warszawa, Poland: Oficyna Ekonomiczna Grupa Wolters Kluwer.

Kot, S., \& Grondys, K. (2011). Theory of inventory management based on demand forecasting. Polish Journal of Management Studies, 3(1), 147-155.

Kuladzhi, T., Babkin, I., Murtazayev, S.-A., \& Golovina, T. (2017). Digital matrix micro forecast of informational and telecommunicational products cost value. Proceedings of the 2017 International Conference
"Quality Management, Transport and Information Security, Information Technologies".

Kyzenko, O., Hrebeshkova, O., \& Grebeshkov, O. (2017). Business intelligence in the economic management of organization. Forum Scientiae Oeconomia, 5(2), 15-27.

Lai, X., Shui, H., \& Ni, J. (2018). A two-layer long shortTerm memory network for bottleneck prediction in multi-job manufacturing systems. ASME 2018 13th International Manufacturing Science and Engineering Conference, MSEC.

Laick, S. (2012). Using Delphi methodology in information system research. International Journal of Management Cases, 14(4), 261-268.

Li, S., Ma, X., \& Yang, C. (2018). A novel structure-adaptive intelligent grey forecasting model with full-order time power terms and its application. Computers and Industrial Engineering, 120, 53-67.

Lin, B., Wong, S. F., \& Ho, W. I. (2015). Study on the production forecasting based on grey neural network model in automotive industry. IEEE International Conference on Industrial Engineering and Engineering Management.

Linstone, H. A., \& Turoff, M. (1975). The Delphi method: techniques and applications. Addison-Wesley Pub. Co.

Maciąg, A., Pietroń, R., \& Kukla, S. (2013). Prognozowanie $i$ symulacja $w$ przedsiębiorstwie [Business forecasting and simulation]. Warszawa, Poland: Polskie Wydawnictwo Ekonomiczne.

Meling, L. M., Morkeseth, P. O., \& Langeland, T. (1988). Production forecasting for gas fields with multiple reservoirs of limited extent. Society of Petroleum Engineers of AIME, (Paper) SPE SIGMA.

Merchant, M. (1970). Technological forecasting and production engineering research. Ann CIRP, 18(1), 5-11.

Mustafa, I. K., \& Jbara, O. K. (2018). Forecasting the food gap and production of wheat crop in Iraq for the period (2016-2025). Iraqi Journal of Agricultural Sciences, 49(4), 560-568.

Mustafaeva, U. Z. (2007). Regression analysis of the dependence of the volume of production on the cost of it. Econ Agric Process Enterprises, 5, 46-47.

Nazarko, J. (Ed.). (2004). Prognozowanie w zarządzaniu przedsiębiorstwem, cz. 2. Prognozowanie na podstawie szeregów czasowych. [Forecasting in business management, part 2. Forecasting based on time series]. Białystok, Poland: Wydawnictwo Politechniki Białostockiej.

Ngadono, T. S., \& Ikatrinasari, Z. F. (2018). Forecasting of PVB Film Using ARIMA. IOP Conference Series: Materials Science and Engineering, 453(1).

Okubo, H., Weng, J., Kaneko, R., Simizu, T., \& Onari, H. (2000). Production lead-time estimation system based on neural network. Proceedings of Asia-Pacific Region of Decision Sciences Institute.

Onaran, E., \& Yanık, S. (2020). Predicting cycle times in textile manufacturing using artificial neural network. Advances in Intelligent Systems and Computing, 1029, 305-312.

Qader, S. H., Dash, J., \& Atkinson, P. M. (2018). Forecasting wheat and barley crop production in arid and semi- 
arid regions using remotely sensed primary productivity and crop phenology: A case study in Iraq. Science of the Total Environment, 613-614, 250-262.

Radziszewski, P., Nazarko, J., Vilutiene, T., Dębkowska, K., Ejdys, J., Gudanowska, A., Halicka, K., Kilon, J., Kononiuk, A., Kowalski, K. J., Król, J. B., Nazarko, Ł., \& Sarnowski, M. (2016). Future Trends in Road Technologies Development in the Context of Environmental Protection. Baltic Journal of Road and Bridge Engineering, 11(2), 160-168.

Rahmat, R. F., Nurmawan, Sembiring, S., Syahputra, M.F., \& Fadli (2018). Adaptive neuro-fuzzy inference system for forecasting rubber milk production. IOP Conference Series: Materials Science and Engineering, 308(1), 012014.

Sagheer, A., \& Kotb, M. (2018). Time series forecasting of petroleum production using deep LSTM recurrent networks. Neurocomputing, 323, 203-213.

Sarma, P., Lawrence, K., Zhao, Y., Kyriacou, S., \& Saks, D. (2018). Implementation and assessment of production optimization in a steamflood using machine-learning assisted modeling. Society of Petroleum Engineers SPE International Heavy Oil Conference and Exhibition, HOCE 2018.

Siderska, J., \& Jadaa K. S. (2018). Cloud manufacturing: a service-oriented manufacturing paradigm. A review paper. Engineering Management in Production and Services, 10(1), 22-31.

Skulmoski, G. J., Hartman, F. T., \& Krahn, J. (2007). The Delphi Method for Graduate Research. Journal of Information Technology Education, 6, 1-21.

Słownik nowy języka polskiego [New polish language dictionary]. (2002). Warszawa, Poland: Wydawnictwo Naukowe PWN.

Sobczyk, M. (2008). Prognozowanie. Teoria, Przykłady, Zadania [Forecasting. Theory, Examples, Tasks]. Warszawa, Poland: Wydawnictwo Placet.

Spicer, J. H. (1970). Cybernetic approach to strategic planning, marketing and production control. Rail International, 1(6), 400-404.

Subramaniyan, M., Skoogh, A., Salomonsson, H., Bangalore, P., \& Bokrantz, J. (2018). A data-driven algorithm to predict throughput bottlenecks in a production system based on active periods of the machines. Computers and Industrial Engineering, 125, 533-544.

Susanto, S., Tanaya, P. I., \& Soembagijo, A. S. (2012). Formulating standard product lead time at a textile factory using artificial neural networks. Proceeding of 2012 International Conference on Uncertainty Reasoning and Knowledge Engineering, URKE 2012, 6319595, 99-104.

Szpilko, D. (2017). Tourism Supply Chain - overview of selected literature. Procedia Engineering, 182, 687-693.

Tariq, Z. (2018). An automated flowing bottom-hole pressure prediction for a vertical well having multiphase flow using computational intelligence techniques. Society of Petroleum Engineers - SPE Kingdom of Saudi Arabia Annual Technical Symposium and Exhibition 2018, SATS 2018.

Tariq, Z., Mahmoud, M., \& Abdulraheem, A. (2019). Realtime prognosis of flowing bottom-hole pressure in a vertical well for a multiphase flow using computational intelligence techniques. Journal of Petroleum Exploration and Production Technology.

Theocharides, S., Makrides, G., Georghiou, G. E., \& Kyprianou, A. (2018). Machine learning algorithms for photovoltaic system power output prediction. 2018 IEEE International Energy Conference, Energycon, 2018, 1-6.

Tkachev, S. I., Voloshchuk, L. A., Melnikova, Y. V., Pakhomova, T. V., \& Rubtsova, S. N. (2018). Economic and mathematical modeling of quantitative assessment of financial risks of agricultural enterprises. Journal of Applied Economic Sciences, 13(3), 823-829.

Trubaev, P. A., \& Tarasyuk, P. N. (2017). Evaluation of energy-saving projects for generation of heat and heat supply by prime cost forecasting method. International Journal of Energy Economics and Policy, 7(5), 201-208.

Wang, A., \& Li, S. (2011). Prediction on the developing trend of global electric automobile based on the logistic model. BMEI 2011 - Proceedings 2011 International Conference on Business Management and Electronic Information.

Wang, C., \& Jiang, P. (2019). Deep neural networks based order completion time prediction by using real-time job shop RFID data. Journal of Intelligent Manufacturing, 30(3), 1303-1318.

Wasilewski, J. (2014). Application of ARIMAX models to short-term electric energy production forecasting at wind micro power plants. Przegląd Elektrotechniczny, 90(7), 135-138.

Wickens, L. M., \& De Jonge, G. (2006). Increasing confidence in production forecasting through risk-based integrated asset modelling, captain field case study. Society of Petroleum Engineers, 68th European Association of Geoscientists and Engineers Conference and Exhibition, incorporating SPE EUROPEC 2006, EAGE 2006: Opportunities in Mature Areas, 6, 3162-3174.

Winkowska, J., Szpilko, D., \& Pejić, S. (2019). Smart city concept in the light of the literature review. Engineering Management in Production and Services, 11(2), 70-86.

Witek-Crabb, A. (2016). Maturity of strategic management in organizations. Oeconomia Copernicana, 7(4), 669 682.

Wu, Y., Hou, F., \& Cheng, X. (2017). Real-time prediction of styrene production volume based on machine learning algorithms. Lecture Notes in Computer Science 10357 LNAI, 301-312.

Yang, L., Lin, H., Gong, Y., \& Zhou, T. (2018). Coalbed methane production forecasting based on dynamic PSO neural network model. ICNC-FSKD 2017 - 13th International Conference on Natural Computation, Fuzzy Systems and Knowledge Discovery.

Yureneva, T., Barinova, O., \& Golubeva, S. (2020). Forecasting the prime cost of milk production in an uncertain environment. Smart Innovation, Systems and Technologies, 138, 678-693.

Yureneva, T. G., \& Barinova, O. I. (2016). Cost differentiation in the dairy industry for short-term forecasting of milk cost. Management Accounting, 4, 28-37. 
Zeliaś, A. (1997). Teoria prognozy [Forecast theory]. Warszawa, Poland: Polskie Wydawnictwo Ekonomiczne.

Zeng, B. L., Chengming L. S., Liu, S., \& Li, C. (2016). A novel multi-variable grey forecasting model and its application in forecasting the amount of motor vehicles in Beijing. Computers \& Industrial Engineering, 101, 479-489.

Zhang, C., Orangi, A., Bakshi, A., Da Sie, W., \& Prasanna, V. K. (2006). Model-based framework for oil production forecasting and optimization: A case study in integrated asset management. 2006 SPE Intelligent Energy Conference and Exhibition, 2, 527-533.

Zhao, H., Huang, F., Li, L., \& Zhang, C. (2018). Optimization of wastewater anaerobic digestion treatment based on ga-bp neural network. Desalination and Water Treatment, 122, 30-35.

Zhou, C. L., \& Liu, M. (2009). Application research on oil production forecasting based on BP neural network. Wuhan Ligong Daxue Xuebao/Journal of Wuhan University of Technology, 31(3), 125-129. 